\title{
Pelatihan Pembuatan Jamur Tiram Crispy di SMPN 14 Tenralili Kabupaten Maros
}

\author{
${ }^{*}$ Elpisah $^{1}$, Andi Tendri2 ${ }^{2}$ Andi Bida ${ }^{3}$ Siti Hajar ${ }^{4}$, Putri Athirah ${ }^{5}$ \\ 1,2,3,4,5STKIP-PI Makassar, Makassar, Indonesia
}

\begin{tabular}{|c|c|}
\hline (A) Check for updates open 0 access c) (i) & DOI: https://doi.org/10.53621/jippmas.v1i2.61 \\
\hline Informasi Artikel & ABSTRAK \\
\hline $\begin{array}{l}\text { Riwayat Artikel: } \\
\text { Diterima: } 10 \text { Oktober } 2021 \\
\text { Revisi Akhir: } 09 \text { November } 2021 \\
\text { Disetujui: } 10 \text { November } 2021 \\
\text { Terbit: } 31 \text { Desember } 2021\end{array}$ & $\begin{array}{l}\text { Tujuan dari kegiatan pengabdian ini adalah memberikan pengetahuan } \\
\text { tambahan mengenai pemanfaatan jamur tiram yang sangat bermanfaat } \\
\text { dan dapat bernilai ekonomis. Metode yang digunakan pada kegiatan } \\
\text { pengabdian ini adalah pelatihan dalam bentuk praktek. Penyampaian } \\
\text { materi pada pelatihan ini dilakukan secara klasikal, semua peserta }\end{array}$ \\
\hline $\begin{array}{l}\text { Kata Kunci: } \\
\text { Jamur Tiram Crispy } \\
\text { SMPN } 14 \text { Tenralili } \\
\text { Pelatihan Pembuatan Jamur } \\
\text { Tiram }\end{array}$ & $\begin{array}{l}\text { mengikuti materi yang disampaikan dengan cara ceramah, diskusi dan } \\
\text { tanya jawab. Hasil dari pelatihan pembuatan jamur tiram crispy adalah: } \\
\text { para guru dan murid dapat memahami dan mengerti mengenai langkah- } \\
\text { langkah dalam pembuatan produk olahan jamur tiram yakni jamur tiram } \\
\text { crispy, para guru dapat mengolah sendiri produk dari jamur tiram yaitu }\end{array}$ \\
\hline 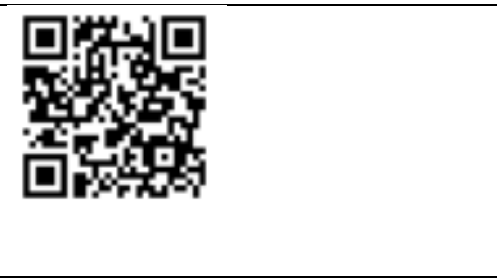 & $\begin{array}{l}\text { jamur tiram crispy yang sudah dipraktekkan, Masyarakat mempunyai } \\
\text { inovasi sendiri kedepannya untuk membuat produk olahan dari jamur } \\
\text { tiram, selain menjadi kamur tiram crispy juga dapat dibuat nugget dan } \\
\text { olahan lainnya, Dapat menjadikan olahan produk jamur tiram sebagai } \\
\text { usaha kecil menengah dan dapat menyokong perekonomian terutama } \\
\text { dapat menambah penghasilan untuk guru-guru karena dapat dibuat } \\
\text { dengan mudah dan dengan bahan alami yang mudah didapatkan. }\end{array}$ \\
\hline
\end{tabular}

\section{PENDAHULUAN}

Jamur tiram (Pleurotus ostreatus) merupakan jenis jamur kayu yang cukup dikenal dan dikonsumsi oleh masyarakat umum karena kandungan gizinya yang tinggi jika dibandingkan dengan jamur lainnya. (Aftukha \& Purbasari, 2021). Jamur tiram kaya akan asam amino esensial seperti valin, leusin, isoleusin, triptofan, treonin, dan fenilalanin. Jamur tiram memiliki tekstur yang lembut dan kenyal serta tinggi serat, sehingga berpotensi sebagai sumber serat pangan sekaligus pengganti protein daging. Permintaan konsumen terhadap komoditas jamur tiram cukup tinggi, yang berarti peluang usaha jamur tiram ini masih sangat terbuka. Dimulai dengan pengadaan bahan baku atau media baglog jamur, budidaya jamur tiram, pemasaran, dan bisnis olahan jamur, maka bisnis jamur tiram dapat dijalankan (Saragih, 2015).

Jamur Tiram Renyah merupakan salah satu jenis jamur yang aman untuk dikonsumsi. Media baglog dapat digunakan untuk membudidayakan jamur ini (serbuk kayu dicampur dengan dedak dan kapur kemudian dibungkus dengan plastik). Perawatannya sederhana, cukup menyiram sekali sehari dengan air bersih sampai jamur siap panen, yang memakan waktu sekitar empat bulan. Saat dipanen, jamur tiram hadir dalam berbagai ukuran, mulai dari yang berdiameter 5 sentimeter hingga yang berdiameter lebih dari 10 sentimeter. Tubuh buah jamur tiram memiliki tangkai yang tumbuh menyamping (bahasa Latin: pleurotus) dan menyerupai tiram (ostreatus), sehingga menimbulkan nama binomial Pleurotus ostreatus. Tudung jamur berubah warna dari hitam, abu-abu, coklat, menjadi putih, dengan permukaan hampir licin, diameter 5-20 cm, dan tepi tudung halus sedikit melengkung. Jamur tiram juga memiliki spora berbentuk batang berukuran $8-113-4 \mathrm{~m}$ dan miselia putih yang dapat tumbuh dengan cepat. Jamur tiram dapat ditemukan di alam liar hampir sepanjang 
tahun di hutan pegunungan yang sejuk. Karena jamur tiram merupakan jenis jamur kayu, tubuh buah dapat terlihat menumpuk di permukaan batang pohon yang membusuk atau batang pohon yang telah ditebang. Alhasil, saat membudidayakan jamur ini, substrat yang dibuat harus memperhatikan habitat aslinya. Serbuk gergaji, produk sampingan dari penggergajian, adalah media berkembang biak yang umum untuk jamur tiram.

Jamur tiram krispi saat ini banyak diminati karena merupakan bahan pangan olahan yang lezat, sehat, dan inovatif. Budidayanya juga sederhana dan murah, sehingga menyebar dengan cepat di Indonesia. Hal yang menarik dari budidaya jamur merang adalah memiliki nilai ekonomi yang tinggi karena tidak membutuhkan lahan yang luas. Selain itu, jamur tiram memiliki nilai gizi yang tinggi dan dianggap memiliki khasiat obat yang dapat digunakan untuk mengobati berbagai penyakit, menjadikannya jenis sayuran yang paling populer. unggul dari sayuran lain karena kandungan nutrisinya yang tinggi Jamur tiram biasanya diolah menjadi keripik jamur dan jamur crispy (Sahadewa et al., 2019).

Jamur Tiram Renyah saat ini adalah jamur yang paling banyak diproduksi secara komersial ketiga di dunia. Setiap tahun, produksi jamur tiram tumbuh di seluruh wilayah Indonesia. Oleh karena itu, diperlukan upaya untuk mengubah jamur tiram menjadi berbagai produk pangan. Hal ini juga didukung dengan semakin berkembangnya masyarakat dalam budidaya jamur tiram, serta harganya yang juga murah (Rahman \& Dwiani, 2014). Karena bahan bakunya mudah didapat dan memiliki prospek yang menjanjikan, budidaya jamur tiram memberikan dampak positif yaitu memacu pertumbuhan ekonomi, dan memiliki peluang yang cukup besar untuk dikomersialkan (Fatmawati, 2021).

Jamur crispy merupakan camilan sehat yang sangat baik untuk dikonsumsi. Selanjutnya, jamur crispy khas Bandung ini memiliki cita rasa yang khas. Menurut temuan, rata-rata jamur mengandung 19-35 persen protein. Kandungan proteinnya lebih tinggi dibandingkan beras $(7,38 \%)$ dan gandum $(13,2 \%)$. Ada sekitar sembilan dari 20 asam amino yang diketahui di antara asam amino esensial yang ditemukan dalam jamur. Jamur tiram memiliki nilai gizi yang tinggi, menurut peneliti dari Ujagar Group di India, karena alasan berikut: 100 persen sayuran dan bersih; kandungan protein dan vitamin dan mineral yang tinggi; rendah karbohidrat, lemak, dan kalori; baik untuk hati, penderita diabetes, dan penurunan berat badan; serat tinggi membantu pencernaan; antivirus dan antikanker; mudah dimasak dan dicerna; dan jamur tiram merupakan jamur yang paling enak jika dibandingkan dengan jamur makanan lainnya. Sebagai perbandingan, tempe berbahan dasar kedelai yang tinggi serat dan merupakan sumber kalsium, vitamin B, dan zat besi yang baik, mengandung 204 kalori, 17 gram protein, 8 gram lemak, 15 gram karbohidrat, 80 mg kalium, Fe (Besi) 2 mg, dan Zn 0,2 mg. Jamur tiram mengandung senyawa yang sangat penting bagi tubuh, seperti ribolamin, niasin, dan selenium. Antioksidannya dapat memerangi radikal bebas, yang menyebabkan kerusakan sel-sel tubuh (Burano, 2020).

Jamur mengandung selenium, yang bermanfaat dalam pencegahan kanker prostat. Karena sebuah penelitian menemukan bahwa mengonsumsi dua porsi per hari dapat menurunkan risiko kanker prostat. Fungsi utama hati adalah sebagai penangkal racun, dan jika tidak dirawat dengan baik, hati berisiko terkena penyakit hati. Jamur tiram memiliki sifat antibakteri dan antitumor yang dapat berperan sebagai penangkal racun dalam tubuh. Jamur mengandung protein tinggi, tetapi rendah kalori dan kolesterol, 
serta memiliki kandungan air yang tinggi hingga 80\%. Jamur juga tinggi serat, yang membantu mereka menurunkan berat badan (Maligan dkk, 2016).

Budidaya jamur tiram dapat dipanen berulang kali dan bertahap. Kardus dan serbuk gergaji merupakan dua jenis media tanam yang dapat digunakan untuk budidaya jamur tiram. Dengan memanfaatkan jamur tiram sebagai pangan alternatif yang sangat bermanfaat bagi kesehatan, maka kami melakukan kegiatan pengabdian pada masyarakat bernilai sebagai gerak penyumbang ilmu dan dasar-dasar kewirausahaan bagi guru-guru dan murid (Rosadi1, 2021).

Hasil PKM Murdiono, (2014) dengan judul Usaha Jamur Renyah "Kriuk" bahwa usaha jamur krispi dapat berkembang dengan baik, namun diperlukan suatu rencana usaha sebagai acuan dalam menjalankan usaha jamur krispi. Murdiono dkk. (2014), Usaha Jamur Crispy "Kriuk" Syarat ketekunan dalam menghadapi persaingan dalam produksi jamur crispy aneka rasa.

Berdasarkan uraian diatas terdapat kendala yang masih banyak dihadapi warga masyarakat (guru dan murid-murid) yaitu kurangnya pengetahuan mengenai manfaat pemanfaatan jamur tiram dapat menghasilkan keuntungan dalam menghasilkan suatu produk olahan rumah tangga yakni dapat dibuat jamur crispy, nugget maupun produk olahan lainnya. Pelatihan pembuatan jamur tiram crispy ini diharapkan dapat menambah wawasan masyarakat dalam memanfaatkan jamur tiram sebagai pangan alternatif yang dapat bernilai ekonomis dan dapat meningkatkan kesehatan masyarakat. Dengan demikian pada akhir kegiatan pelatihan ini warga masyarakat terampil dalam membuat jamur tiram crispy yang kaya akan gizi dan bermanfaat bagi masyarakat yang ingin berwirausaha.

\section{METODE PENELITIAN}

\section{Latar Belakang Umum}

Kegiatan pengabdian masyarakat ini dilaksanakan di SMPN 14 Tanralili Kabupaten Maros selama 40 hari pelatihan. Kegiatan pelatihan pembuatan jamur tiram crispy terdiri dari tiga tahapan, yaitu tahap persiapan, tahap pelaksanaan, dan tahap penutup. Pada kegiatan pengabdian ini, masyarakat diberikan pengatahuan terkait cara pembuatan dan olahan Jamur tiram crispy dengan tujuan melatih masyarakat untuk berwirausaha, bahkan dapat menjual produk jamur tiram crispy sehingga dari penjualan tersebut dapat membantu ekonomi keluarga, serta membudayakan semangat sikap, perilaku, dan kemampuan kewirausahaan di kalangan masyarakat yang mampu, handal, dan unggul serta peduli akan lingkungan. Adapun tahap kegiatan seperti berikut:

\section{Tahan persiapan}

Pada tahap persiapan, tim pengabdian masyarakat malakukan observasi terlebih dahalu untuk melihat masalah yang ada di tempat pelaksanaan PKM. Tim pengabdian mempersentasikan tujuan kegiatan yang akan dilaksanakan dan manfaat dari kegiatan tersebut. Pada tahap ini tim pengabdian dan masyarakat mengatur bagiaman proses dan taknik yang akan dilakukan pada saat kegiatan pengabdian nantinya.

\section{Tahap pelaksanaan}

Pada tahap pelaksanaan dilakukan dengan penyampaian materi secara klasikal berupa pengenalan bahan dan proses pembuatan, dengan metode ceramah, diskusi, 
tanya jawab, selanjutnya dilakukan kegiatan praktek pembuatan Jamur Tiram Crispy.

a. Bahan yang digunakan: Jamur tiram 250 gram, pencelup, tebung terigu $1 \mathrm{Sdm}$, bawang putih, haluskan 3 Sium, gram 1 Sdt, ladah bubuk $1 / 2$ Sdt, air es $150 \mathrm{Ml}$, pelapis tebung terigu 250 gram, tebung beras $2 \mathrm{Sdm}$, baking powder $1 / 2 \mathrm{Sdt}$, merica $1 / 2$ Sdt, gram 1 Sdt.

b. Proses Pembuatan:

1. Cuci bersih jamur, lalu tiriskan. Potong memanjang lalu sisihkan.

2. Dalam satu wadah, aduk rata semua bahan pencelup. Sisihkan.

3. Dalam satu wadah lain. Aduk rata semua bahan pelapis. Sisihkan.

4. Panaskan banyak minyak.

5. Ambil satu potong jamur. Celupkan ke adonan pencelip sampai rata. Lalu gulingkan ke adonan kering sampai terbalur rata. Sambil ditepuk tepuk.

6. Lansung goring jamur di dalam minyak panas, gunakan api sedang. Masak hingga berubah warna jadi kecoklatan. Angkat dan tiriskan.

7. Siap disajikan.

3. Tahap penutup

Pada tahap penutup, ketua tim pengabdian menutup acara kegiatan dan dilanjutkan dengan foto bersama masyarakat pengabdian kali ini. Alur kegiatan pengabdian seperti terlihat pada bagan berikut:

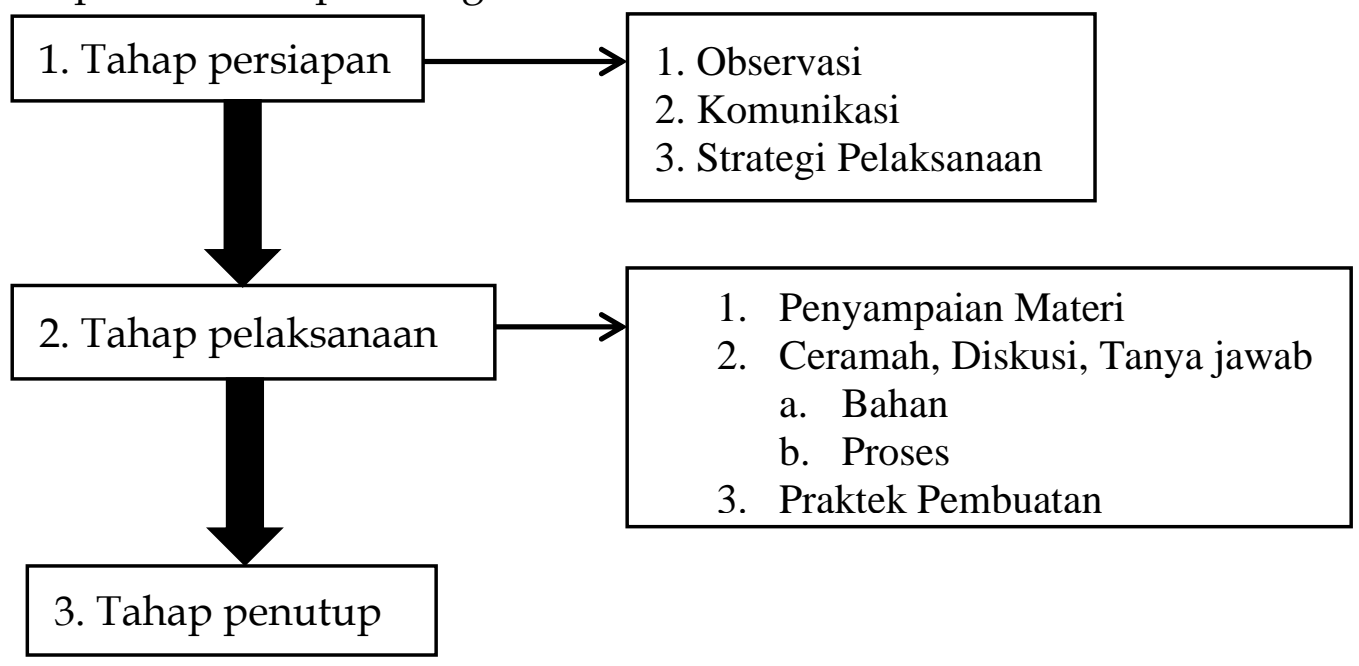

Gambar 1. Tahapan Pelaksanaan Kegiatan

\section{HASIL DAN DISKUSI}

Hasil dari pelatihan pembuatan jamur tiram crispy adalah: para guru dan murid dapat memahami dan mengerti mengenai langkah-langkah dalam pembuatan produk olahan jamur tiram yakni jamur tiram crispy, para guru dapat mengolah sendiri produk dari jamur tiram yaitu jamur tiram crispy yang sudah dipraktekkan.

Masyarakat mempunyai inovasi sendiri kedepannya untuk membuat produk olahan dari jamur tiram, selain menjadi jamur tiram crispy juga dapat dibuat nugget dan olahan lainnya. Dapat menjadikan olahan produk jamur tiram sebagai usaha kecil menengah dan dapat menyokong perekonomian terutama dapat menambah penghasilan untuk guru-guru karena dapat dibuat dengan mudah dan dengan bahan alami yang mudah didapatkan. Pengolahan pascapanen jamur tiram ini merupakan langkah penting dalam upaya mengurangi kerugian akibat produksi jamur yang terus 
meningkat. Teknologi pasca panen merupakan suatu metode untuk memperpanjang umur simpan produk pertanian dan membuat produk pertanian lebih mudah didistribusikan (Panda et al., 2021).

Pengabdian masyarakat sebelumnya yang juga dilakukan oleh tim dari Universitas Palangka Raya berhasil memperkuat pembibitan jamur tiram yang sangat penting bagi kelangsungan hidup petani jamur tiram dalam jangka panjang. Awalnya, tingkat keberhasilan bibit hanya 30\% atau kurang. Hal ini disebabkan kurangnya ruangan steril untuk pembibitan, sehingga rentan terhadap kontaminasi jamur lainnya. Setelah memberikan arahan pembagian ruang budidaya jamur tiram mulai dari pembibitan, inkubasi, dan pertumbuhan jamur, produksi jamur tiram meningkat cukup pesat. Saat ini, bibit jamur tidak lagi menjadi masalah, karena dalam empat bulan terakhir telah mencapai 100\% keberhasilan, sehingga produksi baglog dan jamur terus berlanjut. Akibatnya muncul kekhawatiran pemasaran jamur tiram jika terjadi lonjakan produksi yang tinggi, dan pengolahan pasca panen jamur tiram bisa menjadi solusi permasalahan petani jamur tiram di Sangalang Hapakat Desa Tanjung Sangalang.

Pendekatan yang dilakukan untuk menawarkan solusi atas permasalahan yang di hadapi oleh guru dan muridnya adalah memberikan pelatihan dan peningkatan pengetahun dan penyusunan strategi pemasaran yang tepat dengan menggunakan jamur tiram crispy sebagai produk untuk berwirausaha. Banyaknya manfaat jamur tiram ini bisa dijadikan alasan untuk menjadikan jamur tiram putih sebagai salah satu bahan makanan terbaik untuk dijual. Para peserta juga diberikan gambaran singkat tentang analisis ekonomi jamur tiram putih jika dijual sebagai olahan sate dan jamur crispy (Efendi et al., 2020).

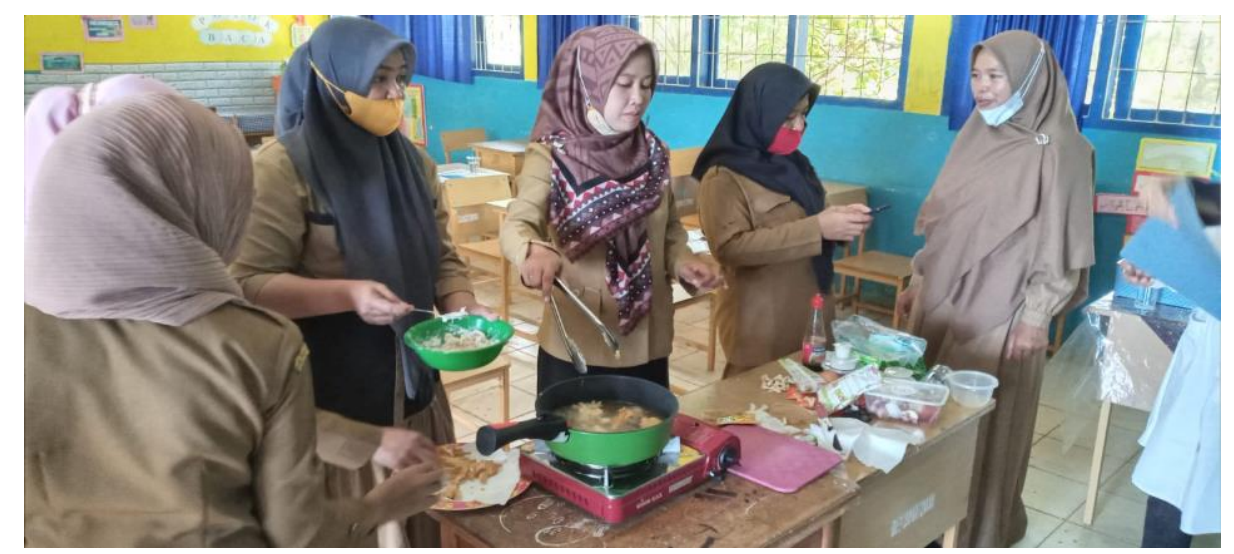

Gambar 2. Proses pembuatan jamur tiram crispy

Kegiatan pengabdian kepada masyarakat antara lain meliputi upaya peningkatan kualitas sumber daya manusia melalui perluasan wawasan, pengetahuan, dan peningkatan keterampilan demi terwujudnya dharma bakti. Kegiatan pengabdian kepada masyarakat merupakan salah satu cara masyarakat untuk terlibat dalam meningkatkan taraf hidup masyarakat dan memberdayakan masyarakat yang lebih luas (Akademika \& Mufidah, 2020).

Efendi et al, (2020) menyatakan bahwa jamur tiram memiliki potensi ekonomi yang tinggi karena kemampuannya untuk diolah menjadi berbagai makanan dan jajanan, serta peluang untuk pengembangan masyarakat. Zulfarina et al, (2019) jamur merupakan produk hortikultura yang tinggi protein. Jamur ini memiliki manfaat yang tidak hanya lezat tetapi juga bermanfaat bagi kesehatan seseorang, seperti menurunkan 
risiko kanker, HIV, dan penyakit lainnya. Potensi produksi jamu dinilai sangat besar, dan berpotensi menghasilkan peluang bisnis. Bisnis jamur krispi merupakan bisnis kuliner yang mirip dengan keripik jamur tiram putih. Proses pembuatan jamur crispy sebenarnya sangat sederhana; sama seperti proses pembuatan ayam goreng crispy; Namun, untuk membuat keripik jamur, Anda hanya perlu menambahkan proses spinner dan menggorengnya lebih lama (karena dimasak sampai kering). Bisnis ini sangat potensial karena harganya yang masih cukup tinggi dan segmentasi pemasaran yang masih cukup terbatas (Warnadi, Aris Triyono, 2020).

Praktik tersebut dilakukan agar dapat mengolah jamur tiram menjadi produk olahan berbahan dasar jamur dengan daya simpan yang lebih lama. Praktik pembuatan produk berbahan dasar jamur disediakan, demikian pula pemilihan jenis kemasan yang sesuai berdasarkan produk yang dibuat. Para peserta diklat juga berlatih menentukan harga jual, sehingga para peserta dapat menentukan harga jual dengan cara yang sederhana yaitu dengan cara markup (Numerasi \& Pra, 2020)

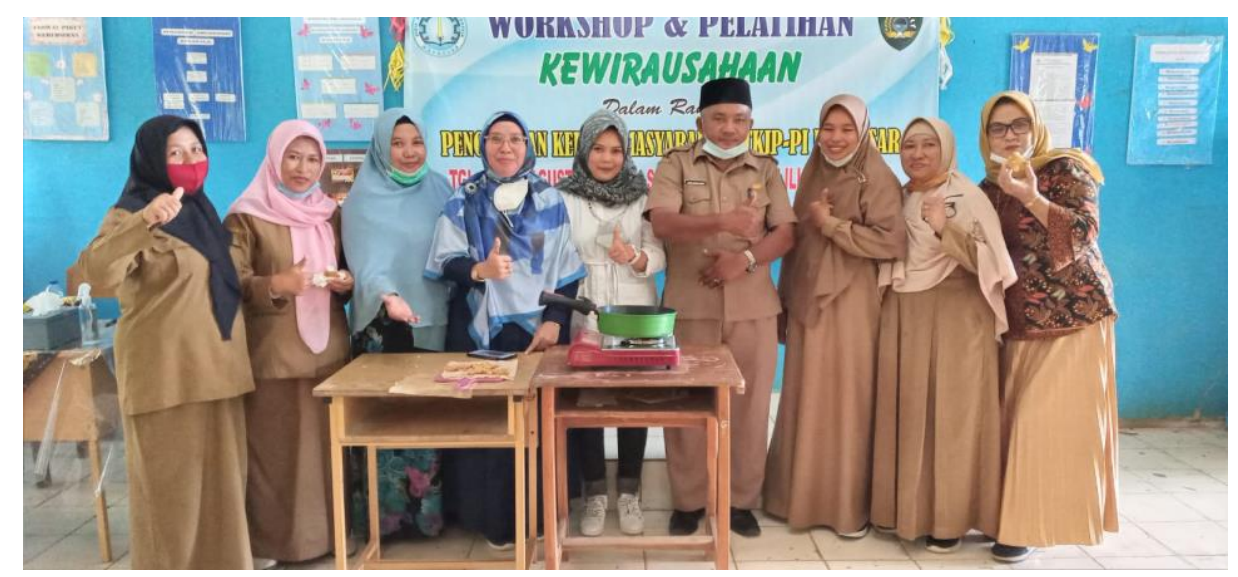

Gambar 3. Pemateri dan perserta pelatihan pembuatan jamur tiram crispy

Jamur tiram banyak diproduksi sebagai bahan makanan karena banyak manfaatnya. Selain budidaya jamur tiram, merupakan salah satu usaha agribisnis dengan peluang bisnis yang cukup besar karena nilai ekonomi jamur tiram meningkat selama sepuluh tahun terakhir (Devi, 2019).

Biasanya jamur tiram diolah menjadi keripik jamur dan jamur crispy. Jamur crispy adalah jamur goreng yang sudah dilapisi tepung bumbu. Jamur crispy memiliki potensi pasar karena peminatnya yang tinggi serta rasanya yang gurih dan lezat. Berkaitan dengan hal tersebut, perlu dilakukan diversifikasi produk olahan jamur tiram yang dapat diminati masyarakat. Nugget merupakan produk olahan yang dapat dijadikan sebagai alternatif. Nugget berpotensi menjadi olahan jamur tiram karena masyarakat saat ini lebih menyukai makanan yang praktis, ekonomis, dan mudah didapat untuk dikonsumsi, Selain itu, nugget memiliki tekstur yang renyah dan gurih jika dibandingkan dengan produk penataan lainnya, menyiratkan bahwa nugget merupakan makanan olahan siap saji yang populer di masyarakat. Jamur tiram putih (pleurotus ostreatus) memakan kayu yang membusuk, serbuk gergaji, limbah jerami, dan limbah kapas. Teksturnya lembut, tampilannya menarik, dan rasanya yang relatif netral, sehingga mudah dipadukan ke dalam berbagai masakan. Budidayanya juga relatif sederhana dan murah, sehingga berpotensi untuk dikomersialkan. Jamur ini sangat populer saat ini (Ramasari, 2015). 
Usaha Jamur Renyah Industri Pengolahan Jamur Tiram merupakan industri rumah tangga yang bergerak di bidang budidaya jamur tiram dan pengolahan pasca panen (Fatria, 2017)

\section{KESIMPULAN}

Berdasarkan analisis hasil kegiatan pelatihan dan observasi yang dilakukan selama pendampingan, maka dapat ditarik kesimpulan sebagai berikut: (1) Pelatihan pembuatan jamur tiram crispy memiliki keterbatasan alat dalam proses pembuatannya, sehingga menghambat proses produksi, (2) Untuk menumbuhkan jiwa wirausaha pada guru dan siswa, pelatihan cara membuat jamur tiram untuk berbagai jenis olahan, seperti nugget jamur tiram, es krim jamur tiram, dan pasta jamur tiram, harus diadakan di sekolah yang sama. (3) Pelatihan cara membuat jamur tiram crispy ini diterima dengan baik oleh para peserta, tingginya minat dan motivasi peserta diklat sangat membantu dalam transfer ilmu dan keterampilan dari dosen kepada peserta pelatihan, sehingga semua materi pelatihan yang diberikan dapat terserap, produk pelatihan berupa jamur tiram crispy dapat dikonsumsi sehari-hari sebagai snack dan lauk pauk, serta dapat dijadikan produk wirausaha.

\section{UCAPAN TERIMA KASIH}

Ucapan terima kasih kami sampaikan kepada STKIP-PI Makassar yang telah mendanai kegiatan pelatihan pembuatan jamur tiram crispy ini. Ucapan terima kasih kami sampaikan kepada perserta SMPN 14 Tanralili Kabupaten Maros.

\section{DAFTAR PUSTAKA}

Aftukha, A. A., \& Purbasari, D. (2021). Karakteristik Mutu Jamur Tiram (Pleurotus ostreatus) Menggunakan Berbagai Metode Pengemasan pada Penyimpanan Suhu Rendah. Jurnal Teknik Pertanian Lampung (Journal of Agricultural Engineering), 10(3), 327. https:/ / doi.org/10.23960/jtep-1.v10i3.327-337

Akademika, A., \& Mufidah, L. (2020). PEMBERDAYAAN MASYARAKAT DESA SINGKIL KULON NGOMBO. Jurnal Abdimas Akademika, 1(2), 9-16.

Burano, R. S. (2020). Strategi Pemasaran Produk Olahan Jamur Tiram di Kelompok Wanita Tani Rosella. Jurnal Menara Ekonomi: Penelitian Dan Kajian Ilmiah ..., VI(2), 70-78. http:/ /jurnal.umsb.ac.id/index.php/menaraekonomi/article/view/1789

Devi, J. (2019). Jamur Tiram Alternative Income Bagi Masyarakat Dusun Jati Desa Jati Dukuh Kec Gondang Mojokerto. Jurnal Abdi Bhayangkara UBHARA Surabaya, 1(1), 1-11.

Efendi, I., Dewi, I. N., Utami, S. D., Harisanti, B. M., \& Primawati, S. N. (2020). Pembinaan Santri Pondok Pesantren NW Kayangan Lombok Barat dalam Pembuatan Produk Olahan Jamur Tiram Berbasis Entrepreneurship. Jurnal Pengabdian UNDIKMA, 1(1), 39-45. https:/ / doi.org/10.33394/jpu.v1i1.2593

Fatmawati*, B. (2021). Pendampingan Pelatihan Budidaya Jamur Tiram Di Pondok Pesantren Ridlol Walidain NW Jenggik. Sasambo: Jurnal Abdimas (Journal of Community Service), 3(1), 17-24. https:// doi.org/10.36312/sasambo.v3i1.338

Fatria, M. A. (2017). Strategi Pengembangan Industri Rumah Tangga Di Kota Pekan Baru ( Sduti Khasus Usaha Jamur Crispy Industri Pengolahan Jamur Tiram). Pengaruh Etika Uang Terhadap Kecuranagan Pajak Dengan Religiusitas, Gender Dan Materialisme Sebagai Variabel Moderasi, 2(2), 2010-2012. 
Numerasi, P., \& Pra, D. (2020). Jurnal Pengabdian Papua. ... Jurnal Yang Dikelola ..., 1(1), 65-69. http:/ / ejournal.uncen.ac.id/index.php/JP/article/view/144

Panda, A., Dirgantara, M., \& Haryono, A. (2021). Pelatihan Pengolahan Jamur Tiram untuk Meningkatkan Keterampilan dan Pendapatan Petani Jamur di Desa Tanjung Sangalang. Agrokreatif: Jurnal Ilmiah Pengabdian Kepada Masyarakat, 7(1), 712. https:/ / doi.org/10.29244/agrokreatif.7.1.7-12

Rahman, S., \& Dwiani, A. (2014). Pengaruh Substitusi Jamur Tiram ( Pleurotus ostreatus) dan Tepung Terigu Terhadap Mutu Kimia Nugget The Effect of Oyster Mushroom ( Pleurotus ostreatus ) and Flour Substitution on Chemical Quality of Nugget. Jurnal Ilmiah INOVASI, 20(2010), 30-34.

Ramasari, R. (2015). Meningkatkan Keterampilan Mambuat Crispy Jamur Tiram Melalui Task Analisis Bagi Anak Tunagrahita Ringan. Http://Ejournal.Unp.Ac.Id/Index.Php/Jupekhu, 4(September), 403-408.

Rosadi1, N. A. (2021). Budidaya Dan Olahan Jamur Tiram Sebagai Penggerak Panti Asuhan Pada Masa Pandemi Covid-19. Jurnal Pengabdian Magister Pendidikan IPA, 4(1), 3-7. https:/ / doi.org/10.29303/jpmpi.v4i1.626

Sahadewa, I. B., Dewi, R. K., \& Dewi, I. A. L. (2019). Analisis Kelayakan Usahatani Jamur Tiram (pleurotus ostreatus) Kasus: Petani Jamur Tiram di Desa Peguyangan Kaja Kecamatan Denpasar Utara. Jurnal Agribisnis Dan Agrowisata (Journal of $\begin{array}{llll}\text { Agribusiness and } & \text { Agritourism), }\end{array}$ https:/ / doi.org/10.24843/jaa.2019.v08.i02.p10

Saragih, R. (2015). Nugget Jamur Tiram (Pleurotus Ostreatus) Sebagai Alternatif Pangan Sehat Vegetarian. Journal WIDYA Kesehatan Dan Lingkungan, 1(2), 90-95. https:/ / media.neliti.com/media/publications/36813-ID-nugget-jamur-tirampleurotus-ostreatus-sebagai-alternatif-pangan-sehat-vegetaria.pdf

Warnadi, Aris Triyono, R. M. I. S. (2020). Pelatiahan Pembuatan Keripik Jamur Tiram Krispy Di Desa Petaling Jaya Kecamatan Batang Cenaku Kabupaten Indragiri Hulu. Jurnal Pengabdian Kepada Masyarakat, 2(1), 16-23.

\footnotetext{
* Dr. Elpisah (Corresponding Author)

STKIP Pembagunan Indonesia Makassar,

Jl. Inspeksi Kanal Citraland No. 10 Makassar, Indonesia

Email: elpisah77.amir@gmail.com

Dr. Andi Tenri

STKIP Pembagunan Indonesia Makassar,

Jl. Inspeksi Kanal Citraland No. 10 Makassar, Indonesia

Email: yeyengatenri@gmail.com

Andi Bida

STKIP Pembagunan Indonesia Makassar,

Jl. Inspeksi Kanal Citraland No. 10 Makassar, Indonesia

Email: bidapurnamasari@gmail.com

Sitti Hajar

STKIP Pembagunan Indonesia Makassar,

Jl. Inspeksi Kanal Citraland No. 10 Makassar, Indonesia

Email: sitihajaraswad90@gmail.com

Putri Athirah

STKIP Pembagunan Indonesia Makassar,

Jl. Inspeksi Kanal Citraland No. 10 Makassar, Indonesia

Email: putriathirah1234@gmail.com
} 